ARTICLE

\title{
Managing pain in children at the end of life: What the GP should know
}

\author{
M A Meiring, MB ChB, FCPaed (SA), MMed (Paed) \\ Department of Paediatrics and Child Health, and Division of Family Medicine, School of Public Health and Family Medicine, Faculty of Health \\ Sciences, University of Cape Town; Sarah Fox Convalescent Hospital, Athlone, Cape Town; and Palliative Treatment for Children (PATCH-SA), \\ Cape Town, South Africa
}

Corresponding author: $M$ A Meiring (ma.meiring@uct.ac.za)

Managing disease- and procedure-related pain in children is paramount. Chronically ill children, especially those requiring repeated procedures or admissions, may experience a significant burden of pain. If poorly managed, it has a negative impact on quality of life and parent-child relationships.

According to the World Health Organization (WHO), the principles of palliative care are applicable to all children with chronic illnesses from the time of diagnosis. A key component of palliative care is good pain management.

S Afr Med J 2014;104(7):512. DOI:10.7196/SAMJ.8462

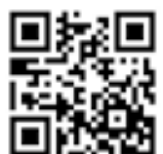

Managing disease- and procedure-related pain in children is paramount. Chronically ill children, especially those requiring repeated procedures or admissions, experience a significant burden of pain. If poorly managed, it has a negative impact on quality of life and parent-child relationships. ${ }^{[1]}$

This article discusses aspects of pain management relevant to most stages of illness, but focuses on the terminal stage. According to the World Health Organization (WHO), the principles of palliative care are applicable to all children with chronic illnesses from the time of diagnosis. ${ }^{[2]}$ Several studies demonstrate the importance of good pain management - not only for the child, but also for the parents and siblings ${ }^{[3]}$ Failure to manage terminal pain adequately may have a lasting impact on the family and result in complicated grief. ${ }^{[4]}$ One of the most commonly expressed wishes of families of dying children is that the death is as pain-free as possible. This can be challenging for professionals and family alike. Some patients and families may request a home death, adding challenges that require creative solutions to try to meet this goal.

In these situations, the general practitioner, who is often more accessible to the family, may be called upon to provide support. This may be daunting for the generalist, especially if the child has been cared for mainly by paediatricians.

Nonetheless, with good forward planning, excellent communication between generalist and specialist, and access to hospice- or homebased care services in the community, this can be achieved, as demonstrated by the case study below.

From the outset, however, families must realise that sometimes matters just don't develop according to plan. Short-term hospitalisation may be required to manage some complications, families may not be able to cope, or the impact on younger siblings may be too overwhelming. Admissions to a hospital or hospice may be necessary and should not be regarded as a failure.

\section{Case study}

John Daniels is the 11-year-old son of Mr and Mrs Daniels, a farming family from a rural area in South Africa. John was first diagnosed with acute lymphoblastic leukaemia at the age of 3 years. He went into remission after his first course of chemotherapy at a tertiary paediatric oncology centre in the nearest city, $1000 \mathrm{~km}$ from the farm. During this time his mother moved in with family in the city to be with him, as he received treatment over 3 years. After being in remission for 2 years, John experienced his first relapse, and once again Mrs Daniels accompanied him to the city. The second treatment course was complicated by several episodes of profound neutropenic sepsis, during which John nearly lost his life. After being disease-free for 3 years, John has unfortunately relapsed again. Given the dismal prognosis following a second relapse, the systemic treatment-related implications and John's last chemotherapy experience, a difficult decision was made, i.e. not to undertake any further active treatment. John's wish is to die at home on the farm surrounded by family and friends. Like his mother, he is a deeply religious Christian and a very sensitive boy, wise beyond his years. He feels very guilty that he demanded so much of his mother's time as a child to the detriment, he believes, of his sisters aged 15 and 9 years. Although he has a good relationship with his father, he feels that his father resents him for all the time his mother had to spend with him away from the farm. The current relapse was noticed during routine screening and John is currently clinically asymptomatic. The paediatric oncologist has written a letter to the local GP and hospice sisters in the rural area, requesting assistance from them in managing his end-of-life stage so that he can spend his last days on the farm.

\section{What kind of pain would John experience as his disease progresses and how would this be assessed?}

In managing the terminal phase of any chronic illness, it is useful to understand the natural pattern of progression of the specific underlying condition and plan for possible scenarios based on an understanding of the pathophysiology. Advance care planning may be a useful tool to help parents prepare themselves for any eventuality. ${ }^{[5]}$ General practitioners can acquire the necessary knowledge, drugs and resources to successfully manage most complications and avoid unnecessary stress for themselves and the family. 
In John's case, the pathophysiological mechanisms resulting in painful symptoms are given in Table 1 .

Table 1. Pathophysiology of pain in leukaemia

\begin{tabular}{|c|c|c|}
\hline Site/system & Pathology & Symptom \\
\hline $\begin{array}{l}\text { Central nervous } \\
\text { system }\end{array}$ & $\begin{array}{l}\text { Meningeal } \\
\text { infiltration }\end{array}$ & $\begin{array}{l}\text { Headache } \\
\text { Neck stiffness }\end{array}$ \\
\hline $\begin{array}{l}\text { Peripheral nervous } \\
\text { system }\end{array}$ & $\begin{array}{l}\text { Chemotherapy- } \\
\text { related nerve } \\
\text { damage }\end{array}$ & $\begin{array}{l}\text { Peripheral } \\
\text { neuropathy }\end{array}$ \\
\hline Lymphatic system & $\begin{array}{l}\text { Lymphatic } \\
\text { infiltration } \\
\text { Splenic infiltration }\end{array}$ & $\begin{array}{l}\text { Nociceptive and/or } \\
\text { neuropathic pain }\end{array}$ \\
\hline Abdomen & $\begin{array}{l}\text { Hepatic infiltration } \\
\text { Capsular stretch } \\
\text { Abdominal node } \\
\text { infiltration } \\
\text { Ileus }\end{array}$ & $\begin{array}{l}\text { Nociceptive and/or } \\
\text { neuropathic pain }\end{array}$ \\
\hline Bone & $\begin{array}{l}\text { Cortical infiltration } \\
\text { Pathological } \\
\text { fractures } \\
\text { Periosteal stretch } \\
\text { Infiltration of } \\
\text { haversian canals }\end{array}$ & $\begin{array}{l}\text { Nociceptive bone } \\
\text { pain } \\
\text { Neuropathic bone } \\
\text { pain }\end{array}$ \\
\hline
\end{tabular}

The cornerstone of good pain management is proper assessment. The gold standard of pain assessment is patient self-reporting, using the PQRST acronym: $\mathrm{P}=$ provoking and palliating factors, $\mathrm{Q}=$ quality and quantity, $\mathrm{R}=$ region and radiation, $\mathrm{S}=$ severity, and $\mathrm{T}=$ timing (Table 2). ${ }^{[7]}$

A particularly useful tool in evaluating multiple sites and sources of pain in leukaemia is the Eland body tool. ${ }^{[8]}$ The child is given an outline drawing of the front and back of a child and is asked to select four coloured crayons or pencils: one for no pain, and one for mild, one for moderate and one for severe pain. The child may also choose to leave the unaffected parts of the body white. The child is then asked to colour his/her body as per the severity of the pain in the different parts of his/ her body according to his/her chosen colour code.

When assessing pain one must realise that pain is not only physical. Cicely Saunders, the founder of the modern hospice movement, was the first to describe the concept of 'total pain. ${ }^{[9]}$ Apart from its physical manifestations, pain also has psychological, spiritual and social components, which are particularly important at the end of life.

Psychologically, pain and its implications may evoke considerable anxiety. Failure to assess and manage this may make physical pain difficult to control. In John's case, coming from a deeply religious family, it would be important to explore the possibility of existential or spiritual pain, as his faith may help him to be at peace with dying. Socially, John has feelings of guilt for having consumed so much of his mother's time over the years to the perceived disadvantage of his sisters and father. Time at home would provide an important opportunity for him to address these perceptions and to experience a greater sense of intimacy with his whole family.

\section{How would the GP manage John's escalating pain?}

Mrs Daniels, as John's primary caregiver, is an important partner in managing John's pain as his disease progresses. One of the key components of successful pain management at home is accurate reporting to detect changes in the patient's condition and to carry out mutually agreed instructions. The assistance of a home-based care worker or hospice nurse to provide an objective second opinion is particularly useful, as objectivity may be lost if the primary caregiver becomes overwhelmed.

In managing John's pain, the following broad management principles apply:

\section{General principles of pain management}

- Determine and treat the underlying cause (where possible) of pain, including non-physical causes

- Relieve pain without creating new symptoms or unwanted side-effects

- Consider both drug and non-drug interventions

- Consider whether treatment is beneficial to the individual patient

Non-drug measures useful in managing pain in children are given in Table 3. ${ }^{[10]}$

Table 3. Non-drug measures for pain control

\begin{tabular}{ll}
\hline Counter-irritation & Psychological methods \\
\hline Heat & Distraction \\
Cold & Imagery \\
Touch/massage & Relaxation \\
Transcutaneous electrical nerve & Cognitive-behavioural therapy \\
stimulation (TENS) & \\
Acupuncture & Music therapy \\
Vibration & Biofeedback \\
Aromatherapy & Hypnosis
\end{tabular}

Table 2. PQRST acronym for pain assessment ${ }^{[7]}$

\begin{tabular}{|c|c|c|}
\hline $\mathrm{P}$ & Palliating and provoking factors & What makes the pain better? What makes it worse? \\
\hline Q & Quality and quantity & $\begin{array}{l}\text { Descriptions of the nature of the pain help to determine whether it is nociceptive (sharp, well } \\
\text { localised) or neuropathic (shooting pain) }\end{array}$ \\
\hline $\mathrm{R}$ & Region and radiation & Helps with localisation, determining source of pain \\
\hline S & Severity & $\begin{array}{l}\text { Scales may be useful to rate severity and monitor response to treatment, e.g. face, legs, activity, cry, } \\
\text { consolability (FLACC), faces scale (revised) or visual analogue scale (VAS) }\end{array}$ \\
\hline $\mathrm{T}$ & Timing & Time of day, how long it lasts \\
\hline
\end{tabular}


As John's pain will probably be mostly of bone origin, but could also include abdominal pain and headache, the pathophysiological mechanisms include both nociceptive and neuropathic mechanisms necessitating the use of classic analgesics and co-analgesics (previously called adjuvants)

The gold standard of cancer pain management is provided by the WHO 3-step ladder as shown in Fig. 1. ${ }^{[11]}$

Doses for and notes on commonly used analgesics in children are given in Table 4.

John's pain may initially be manageable with weak opioids such as tilidine (Valoron) in combination with paracetamol. The cumbersome drop formulation and expense of tilidine may limit its use; if syrups are preferred, the drops can be added to liquid paracetamol. In the public sector, morphine is more commonly

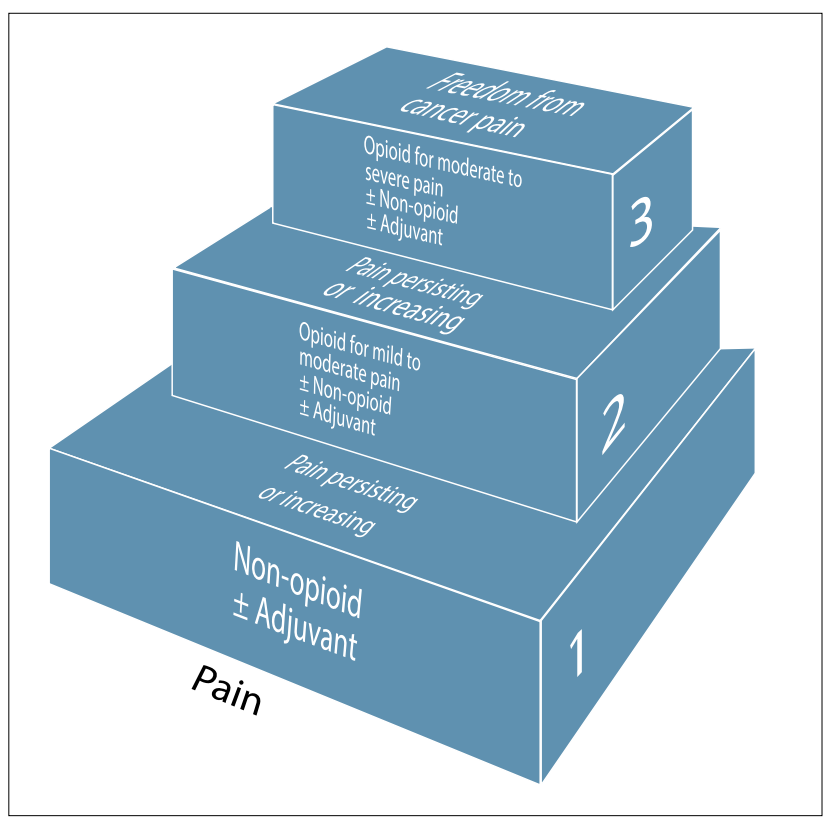

Fig. 1. The World Health Organization pain ladder. given to outpatients. According to the new WHO guidelines, a lower dose of morphine may be used at step 2 of the WHO ladder. ${ }^{[12]}$ Because of its variable bioavailability, codeine is no longer recommended for pain management in children. ${ }^{[13]}$ An alternative weak opioid that may be used is tramadol, although its use is off licence in patients $<18$ years. To optimise dose increases, single agents rather than combinations of drugs are preferred.

To manage the neuropathic component of John's bone pain a co-analgesic may be necessary, e.g. a low dose of prednisone. Nonsteroidal anti-inflammatory drugs (NSAIDs), with their potential effects on platelets, should be avoided in patients with leukaemia. ${ }^{[14}$ Gabapentin (e.g. Neurontin) provides good neuropathic pain cover and has fewer side-effects and drug interactions than the more classic co-analgesics, e.g. amitriptyline and carbamazepine. ${ }^{[15]}$

Doses of common co-analgesics and other drugs useful in managing chronic pain in children are shown in Table 5.

As John's pain increases, he will eventually need more potent opioids. Morphine remains the gold standard strong opioid. Shortacting morphine must be given regularly at 4-hourly intervals and not as required. Exceptions to 4-hourly dosing are in cases of hepatic or renal compromise, where dosing intervals are 6- and even 8-hourly. Extra doses (50 - 100\% of the regular dose) should be provided for breakthrough pain.

If John's pain settles on a regular short-acting dose every 4 hours, long-acting morphine given every 12 hours may be more convenient (although some children may need 8-hourly dosing). To determine the dose of long-acting morphine, the total amount of short-acting morphine required over 24 hours should be calculated and halved. This dose should be rounded up or down to the available formulations. Long-acting morphine (e.g. MST Continus) is available in $10 \mathrm{mg}, 30 \mathrm{mg}, 60 \mathrm{mg}$ and $100 \mathrm{mg}$ tablet strengths.

Patients on long-acting morphine may still experience breakthrough pain and breakthrough doses of short-acting morphine (1/6 of the total MST Continus dose) should be prescribed. As pain escalates, the dose of long-acting morphine should be increased based on the

Table 4. Commonly used analgesics for pain management in children - palliative care in the home setting

\begin{tabular}{lll}
\hline Drug & Dose & Notes \\
\hline Paracetamol & Oral: loading dose: $20 \mathrm{mg} / \mathrm{kg}$, then $15 \mathrm{mg} / \mathrm{kg} /$ dose 6-hourly & $\begin{array}{l}\text { Decrease dose and increase dosing interval to } \\
\text { Rectal: } 30 \mathrm{mg} / \mathrm{kg} \text { stat, then } 20 \mathrm{mg} / \mathrm{kg} 4-6 \text {-hourly }\end{array}$ \\
Ibuprofen & Oral: $5-10 \mathrm{mg} / \mathrm{kg} 6-8$-hourly, max. $30 \mathrm{mg} / \mathrm{kg} /$ day in $3-4$ & Give with food \\
& divided doses & $\begin{array}{l}\text { Avoid with asthma, low platelets, peptic ulcer } \\
\text { disease and renal dysfunction }\end{array}$
\end{tabular}

Note: codeine is no longer recommended for pain management

Tramadol

$<50 \mathrm{~kg}: 1$ - $2 \mathrm{mg} / \mathrm{kg} /$ dose 3 - 6-hourly (max. $8 \mathrm{mg} / \mathrm{kg} /$ day) $>50 \mathrm{~kg}$ : 50 - $100 \mathrm{mg} 3$ - 6-hourly (max. $400 \mathrm{mg} /$ day)

Tilidine

Morphine sulphate

Long-acting morphine
Oral: $1 \mathrm{mg} / \mathrm{kg} /$ dose 6 -hourly = $1 \mathrm{drop} / 2.5 \mathrm{~kg}$ body weight

Oral: <1 month: $0.05 \mathrm{mg} / \mathrm{kg} /$ dose 4 - 6-hourly

1 - 12 months: $0.1 \mathrm{mg} / \mathrm{kg} /$ dose 4 -hourly

$>12$ months: $0.2-0.4 \mathrm{mg} / \mathrm{kg} /$ dose 4 -hourly

Subcutaneous: total oral morphine requirement over 24 hours divided by 2

Dose determined from total 24-hour short-acting morphine requirements and halved

Remember to provide short-acting breakthrough doses
Syrup $5 \mathrm{mg} / \mathrm{ml}$ or crush $6 \times 50 \mathrm{mg}$ tabs and add to $30 \mathrm{ml} \mathrm{Ora-Plus}+30 \mathrm{ml}$ Ora-Sweet solution

Contraindicated in head injuries with raised intracranial pressure, asthma

Increase dosing interval, especially in premature neonates and patients with renal or hepatic impairment

Round up to available tablets: $10 \mathrm{mg} / 30 \mathrm{mg} / 60$ $\mathrm{mg} / 100 \mathrm{mg}$ 
Table 5. Co-analgesics and other useful drugs in pain management in children

\begin{tabular}{|c|c|c|}
\hline Drug & Dose & Notes \\
\hline Amitriptyline & $\begin{array}{l}2-12 \text { years: } 0.1-0.2 \mathrm{mg} / \mathrm{kg} \text { at night. Increase to max. } 1-2 \\
\mathrm{mg} / \mathrm{kg} \text { at night over } 1-2 \text { weeks } \\
12-18 \text { years: } 10-25 \mathrm{mg} \text { po at night. Increase to max. } 5 \mathrm{mg}\end{array}$ & $\begin{array}{l}\text { Do ECG before using } \\
\text { Contraindicated in cases of prolonged QT interval } \\
\text { Pain dose is lower than for depression }\end{array}$ \\
\hline Carbamazepine & $\begin{array}{l}5 \text { - } 20 \mathrm{mg} / \mathrm{kg} / \text { day in } 2 \text { or } 3 \text { divided doses. Increase gradually } \\
\text { to avoid side-effects (not the drug of choice but more readily } \\
\text { available) }\end{array}$ & $\begin{array}{l}\text { Induces cytochrome P450 } \\
\text { Drug interactions with antiretrovirals } \\
\text { Can cause pancytopenia }\end{array}$ \\
\hline Gabapentin & $\begin{array}{l}2 \text { - } 12 \text { years: } 3-5 \mathrm{mg} / \mathrm{kg} / \text { dose. Start at night, then bd, then tds } \\
\text { Increase to } 10-20 \mathrm{mg} / \mathrm{kg} / \text { dose } \\
12 \text { - } 18 \text { years: } 300 \mathrm{mg} \text { on day } 1 ; 300 \mathrm{mg} \text { bd on day } 2 ; 300 \mathrm{mg} \text { tds } \\
\text { on day 3. Max. } 1200 \mathrm{mg} \text { tds }\end{array}$ & $\begin{array}{l}\text { Avoid sudden withdrawal } \\
\text { Do not use in patients with a history of psychiatric } \\
\text { illness }\end{array}$ \\
\hline Corticosteroids & Prednisone $1-2 \mathrm{mg} / \mathrm{kg} /$ day & $\begin{array}{l}\text { Useful for neuropathic pain, bone pain, immune } \\
\text { reconstitution inflammatory syndrome }\end{array}$ \\
\hline Clonidine & $1-4 \mu \mathrm{g} / \mathrm{kg} /$ dose 6 - 12-hourly (useful with pain and anxiety) & $\begin{array}{l}\text { Caution in renal failure, vascular disease, } \\
\text { depression }\end{array}$ \\
\hline Diazepam & $\begin{array}{l}1-6 \text { years: } 1 \mathrm{mg} / \text { day in } 2-3 \text { divided doses } \\
6-14 \text { years: } 2-10 \mathrm{mg} / \text { day in } 2-3 \text { divided doses }\end{array}$ & Use for associated anxiety and muscle spasm \\
\hline $\begin{array}{l}\text { Hyoscine butylbromide } \\
\text { (Buscopan) }\end{array}$ & $\begin{array}{l}1 \text { month - } 2 \text { years: } 0.5 \mathrm{mg} / \mathrm{kg} / \mathrm{dose} \text { po } 8 \text {-hourly } \\
2 \text { - } 5 \text { years: } 5 \mathrm{mg} \text { po } 8 \text {-hourly } \\
6 \text { - } 12 \text { years: } 10 \mathrm{mg} \text { po } 8 \text {-hourly }\end{array}$ & $\begin{array}{l}\text { Use for colicky abdominal pain } \\
\text { Can cause nausea, dry mouth and constipation }\end{array}$ \\
\hline
\end{tabular}

Example 1. Patient receives $10 \mathrm{mg}$ short-acting morphine sulphate (syrup formulation) every 4 hours

- To convert this to long-acting morphine, use the following calculation:

the total dose of morphine used over 24 hours $=10 \mathrm{mg} \times 6$ $=60 \mathrm{mg} \div 2=30 \mathrm{mg}$. Therefore, give long-acting morphine $30 \mathrm{mg}$ orally 12-hourly. NB: Continue to give breakthrough doses of shortacting morphine (10 mg)

Example 2. Patient receives $30 \mathrm{mg}$ long-acting morphine 12-hourly and has received 5 breakthrough doses of $10 \mathrm{mg}$ short-acting morphine

- To increase the dose of long-acting morphine: the total morphine dose over 24 hours $=(30 \mathrm{mg} \times 2)+(10 \mathrm{mg} \times$ $5)=60 \mathrm{mg}+50 \mathrm{mg}=110 \mathrm{mg} \div 2=55 \mathrm{mg}$. MST Continus is only available in $10 \mathrm{mg}, 30 \mathrm{mg}, 60 \mathrm{mg}$ and $100 \mathrm{mg}$ tablet strengths. One could increase the dose to $60 \mathrm{mg} 12$-hourly. Continue to give breakthrough doses of $120 \mathrm{mg} \div 6=20 \mathrm{mg}$ of short-acting morphine

breakthrough dose requirements. See an example of the calculation in the box above.

\section{What is the maximum dose of morphine that John may receive?}

In progressive malignant disease there is no maximum dose of morphine, which can be scary for GPs not used to administering very high doses of the drug. While the most-feared side-effect is usually respiratory depression, pain itself is the physiological antagonist to this effect. Therefore, as long as the morphine dose is titrated against real pain, respiratory depression will not occur. ${ }^{[16]}$ By definition, a potent opioid has no ceiling effect, i.e. increasing doses will improve pain control provided true tolerance has not developed (discussed below). ${ }^{[17]}$

Morphine can either be increased in increments of $30 \%$ of the previous day's dose or by calculating requirements based on the preceding 24 hours breakthrough doses, as shown in the examples above.
What side-effects may the GP expect and how should these be managed?

Table 6 outlines the most common side-effects of morphine and their management.

Tolerance develops to most of morphine's minor side-effects (sedation, nausea and pruritus), with the exception of constipation. Therefore, over time (usually 3 - 5 days), the foregoing side-effects are no longer experienced. Clinically, this translates into either 'waiting it out' or prescribing short-term symptom control drugs (e.g. antiemetics) until tolerance has developed. ${ }^{[18]}$

In adults and older children laxatives are generally prescribed prophylactically to avoid constipation, although in infants and younger children this may not always be necessary.

\section{What would the GP do if it appeared that increased doses of morphine were no longer effective? \\ Tolerance is defined as a 'phenomenon whereby chronic exposure} to a drug diminishes its anti-nociceptive effect, or creates the need for a higher dose to maintain this effect: ${ }^{[19]}$ Clinically, this definition assumes no progression in the disease state. Increased pain is most commonly due to increasing tumour burden in malignancy.

True tolerance may occasionally develop. One should then consider switching to a different opioid. Intolerable side-effects of one opioid may also warrant switching to another. Switching to fentanyl patches is common (as described below), but opioid rotation may be beyond the scope of the GP and specialist assistance should be sought. Commonly used alternative strong opioids include oxycodone, methadone and fentanyl.

\section{What if John is no longer able to take his medication orally?}

Decreased ability to take oral medication may result from difficulty in swallowing or more commonly because of a decreasing level of consciousness as death approaches. Unconscious patients still feel pain as the perception thereof also occurs at a subcortical level. ${ }^{[20]}$ Sudden withdrawal of opioids can result in unpleasant withdrawal symptoms. ${ }^{[21]}$ 
Table 6. Management of common side-effects of morphine

\begin{tabular}{lll}
\hline Gastrointestinal & Nausea and vomiting & Usually development of tolerance \\
& Constipation & Laloperidol is the most commonly prescribed anti-emetic \\
Autonomic & Xerostomia & Good oral care, ice cubes \\
& Urinary retention & Bladder massage, urinary antispasmodics, catheterisation \\
Central nervous system & Drowsiness & Usually development of tolerance. Methylphenidate has been used in chronic cases \\
& Respiratory depression & Naloxone \\
& Myoclonus & Baclofen, diazepam, opioid rotation \\
& Hyperalgesia & Opioid rotation \\
Cutaneous & Itch & Antihistamines or paroxetine, opioid rotation if chronic \\
& Sweating & Symptomatic
\end{tabular}

Table 7. Conversion table: Oral morphine to fentanyl patch

\begin{tabular}{lllllll}
\hline 24-hour oral morphine requirement $(\mathrm{mg})$ & $<67$ & $68-135$ & $135-224$ & $225-314$ & $315-404$ & $405-494$ \\
Fentanyl patch $(\mu \mathrm{g})$ & 12 & 25 & 50 & 75 & 100 & 125
\end{tabular}

A number of alternative routes can be used in the home setting, depending on available resources. A nasogastric tube, if acceptable and tolerated, can provide a useful route of drug administration, but by far the most widely practised alternative route in the hospice setting is via continuous subcutaneous infusion of drugs by means of a small portable pump. ${ }^{[22]}$ The syringe pump (also called the 'syringe driver') is a simple battery-operated mechanical device that can be used in the home setting to manage almost every end-of-life symptom, provided it can be set up and checked regularly by a hospice nurse trained in its use. ${ }^{[23]}$

The fentanyl patch (e.g. Durogesic), which is a transdermal therapeutic system, is also particularly useful in managing patients no longer able to take regular oral morphine. A conversion table is used to decide on patch strength based on the 24-hour morphine requirements (Table 7). As it takes up to 12 hours for the patch to release a sufficient amount of fentanyl to achieve steady state, the patient should continue to receive morphine (either one long-acting dose or three short-acting doses) for the first 12 hours after application of the patch. It is important to remember that breakthrough pain may still be experienced when using a fentanyl patch and that extra morphine (an equivalent dose) must be provided. Patch strength should be increased according to ongoing morphine requirements. Patches should be changed every 72 hours, although in some patients (particularly children) this may need to be performed every 48 hours as metabolism may be more rapid. Only matrixed fentanyl patches (Durogesic DTrans, Durogesic SMAT, or Matrifen) may be cut. ${ }^{[24]}$

Extraordinary measures may be required to manage pain at the end of life, including palliative radiotherapy and short-term hospitalisation for intravenous therapy, especially with ketamine. If pain is not manageable in the home setting, the GP should consult with the specialist to consider hospitalisation. No child should be allowed to die with uncontrolled pain.

Finally, the impact of caring for a child (especially with difficultto-manage pain) at the end of life on the healthcare professional (GP, nurse, specialist) should not be underestimated and professionals should ensure that they care for themselves and have access to the necessary debriefing support when necessary. ${ }^{[25]} \mathrm{A}$ well-managed and expected 'good' death, however, can also bring with it a tremendous sense of professional satisfaction, despite the loss.

\section{References}

1. Hongo T, Watanabe C, Okada S, et al. Analysis of the circumstances at the end of life in children with cancer: Symptoms, suffering and acceptance. Pediatr Int 2003;45:60-64. [http://dx.doi.org/10.1046/ j.1442-200X.2003.01668.x

2. World Health Organization. WHO definition of palliative care. http://www.who.int/cancer/palliative/ definition/en/ (accessed 20 March 2014).

3. Hechler T, Blankenburg M, Friedrichsdorf SI, et al. Parents' perspective on symptoms, quality of Hechler $\mathrm{T}$, Blankenburg $\mathrm{M}$, Friedrichsdorf S, et al. Parents' perspective on symptoms, quality of
life, characteristics of death and end-of-life decisions for children dying from cancer. Klin Pädiatr life, characteristics of death and end-of-life decisions for children

4. Zhang B, El--Jawahri A, Prigerson HG. Update on bereavement research: Evidence-based guidelines for Zhang B, El-Jawahri A, Prigerson HG. Update on bereavement research: Evidence-based guidelines for
the diagnosis and treatment of complicated bereavement. J Palliat Med 2006;9(5):1188-1203. [http:// the diagnosis and treatment of complicated bereavement. J Palliat Med 2006;9(5):1188-1203. [http:// dx.doi.org/10.1089/jpm.2006.9.1188]

5. Wharton RH, Levine KR, Buka S, Emanuel L. Advance care planning for children with special health care needs: A survey of parental attitudes. Pediatrics 1996;97(5):682-687.

6. Luger NM, Mach DB, Sevcik MA, Mantyh BW. Bone cancer pain: From model to mechanism to therapy. J Pain Symptom Manage 2005;29:S32-S46. [http://dx.doi.org/10.1016/j.jpainsymman.2005.01.008]

. Murphy JP. The ABC's of pain. Mnemonics in the field of pain medicine provide practical and useful devices for mental checklists. http://www.practicalpainmanagement.com/resources/abc-pain (accessed 20 March 2014)

8. Moon EC, McMurphy CM, McGrath PI. Child and adolescent pain. In: Hunslie J. A Guide to Assessments That Work. Oxford: Oxford University Press, 2008:558-559. http://www.painresearch. utah.edu/cancerpain/attachb6.html (accessed 20 March 2014).

9. Clark D. 'Total pain', disciplinary power and the body in the work of Cicely Saunders, 1958-1967. Soc Sci Med 1999;49(6):727-736. [http://dx.doi.org/10.1016/S0277-9536(99)00098-2]

10. Kuttner L. Pain - an integrative approach. In: Goldman A, Hain R, Liben S, eds. Oxford Textbook of Kuttner L. Pain - an integrative approach. In: Goldman A, Hain R, Liben S,
Palliative Care for Children. Oxford: Oxford University Press, 2006:332-341.

11. World Health Organization. WHO Ladder: Cancer Pain Relief and Palliative Care. Technical Report Series 804. Geneva: World Health Organization, 1990. http://www.who.int/cancer/palliative/ painladder/en/ (accessed 20 March 2014)

12. World Health Organization. WHO guidelines on the pharmacological treatment of persisting pain in children with medical illnesses. http://whqlibdoc.who.int/publications/2012/9789241548120 Guidelines.pdf (accessed 20 March 2014).

13. Williams DG, Hatch DJ, Howard RF. Codeine phosphate in paediatric medicine. Br J Anaesth 2001;86:413-421. [http://dx.doi.org/10.1093/bja/86.3.413]

14. Schafer AI. Effects of non-steroidal anti-inflammatory drugs on platelet function and systemic hemostasis. J Clin Pharmacol 1995;35(3):209-219. [http://dx.doi.org/10.1002/j.1552-4604.1995. tb04050.x]

15. Backonja M, Glanzman RL. Gabapentin dosing for neuropathic pain: Evidence from randomized, placebo controlled clinical trials. Clin Ther 2003;25(1):81-104. [http://dx.doi.org/10.1016/S01492918(03)90011-7]

6. Gallagher R. Killing the symptom without killing the patient. Can Fam Physician 2010;56:544-546

17. Kay B. Narcotic analgesia-ceiling effect. Anesthesiology 1985;62(3):371-372. [http://dx.doi. org/10.1097/00000542-198503000-00035]

18. Cherny N, Ripamonti C, Pereira J, et al. Strategies to manage the adverse effects of oral morphine: An evidence-based report. J Clin Oncol 2001;19:2542-2554.

19. Collett BJ. Opioid tolerance: The clinical perspective. Br J Anaesth 1998:81:58-68.

20. Laureys S, Owen AM, Schiff ND. Brain function in coma, vegetative state, and related disorders. Lancet Neurol 2004;3(9):537-546. [http://dx.doi.org/10.1016/S1474-4422(04)00852-X]

1. Grégoire MC, Frager G. Ensuring pain relief for children at the end of life. Pain Res Manag 2006;11(3):163-171

22. Miser AW, Davis DM, Hughes CS, Mulne AF, Miser JS. Continuous subcutaneous infusion of morphine in children with cancer. Am J Dis Child 1983;137:383-385.

23. Liben S, Goldman A. Home care for children with life-threatening illness. J Palliat Care 1998;14:33-38

24. Finkel JC, Finley A, Greco C, Weisman SJ, Zeltzer L. Transdermal fentanyl in the management of children with chronic severe pain. Cancer 2005;104 (12):2847-2857. [http://dx.doi.org/10.1002/ cncr.21497]

25. Kirby J, Lück P. Physician self-care. S Afr Med J 2014;104(7):513. [http://dx.doi.org/10.7196/ SAMJ.8472] 